\title{
Microarray detection of human papilloma virus genotypes among Turkish women with abnormal cytology at a colposcopy unit
} Bir Kolposkopi merkezine başvuran anormal sitolojili Türk kadınlarındaki human
papilloma virus tiplerinin mikroarray analizi Işıl Uzun Çilingir ${ }^{1}$,Ergin Bengisu' ${ }^{1}$, Ali Ağaçfidan², Muammer Osman Koksal², Samet Topuz ${ }^{1}$, Sinan Berkman ${ }^{1}$, Ahmet $^{2}$

\author{
Cem Iyibozkurt ${ }^{1}$ \\ 'Department of Obstetrics and Gynecology, Istanbul University, Istanbul Medical School, Istanbul, Turkey \\ ${ }^{2}$ Department of Microbiology, Istanbul University, Istanbul Medical School, Istanbul, Turkey
}

\section{Abstract}

Objective: There is a well-known association between human papilloma virus (HPV) and cervical neoplasia. The aim of this study was to investigate the types of HPV DNA and to compare the results with colposcopic findings among women with abnormal cytology.

Material and Methods: A series of 76 consecutive women attending the clinic with the usual referral indications (ASC-US or higher in Pap) were examined by the conventional diagnostic tools (PAP smear, colposcopy,punch biopsy) and subjected to HPV testing. For HPV genotyping, we used a commercially avaliable HPV DNA chip (Genomica-CLART) which is a PCR based microarray system.The HPV test detected 35types of HPV (HPV-6/-11/-16/-18/-26/-31/-33/-35/39/-40/-42/-43/-44/-45/-51/-52/-53/-54/-56/-58/-59/-61/-62/-66/-70/-71/$72 /-73 /-81 /-83 / 84 /-85 /-89)$.

Results: Overall, $44.7 \%$ of all patients were HPV positive. HPV was positive in $35 \%, 51.9 \%, 77.7 \%$ of the ASCUS, LSIL and HSIL groups respectively and HPV 16 was the most prevalent type in all groups. 6 $\%$ of patients had mutiple infections. $57.8 \%$ of biopsy proven SIL's were HPV positive. The most prevalent HPV type was HPV 16 (54.5\%).Colposcopic assessment revealed pathologic findings in $94.7 \%$ of biopsy proven SIL cases.

Conclusion: Although it has been reported that the prevalence of HPV in the general population is lower than Western countries, and the prevalence and distribution of genotypes are smilar in patients with abnormal cytology. Further population based studies are needed to determine the prevalance and type distribution of HPV with normal and abnormal cytology in Turkish women. Despite the new technological progress in HPV virion, colposcopy is still very important diagnostic tool in the management of abnormal smears.

(J Turkish-German Gynecol Assoc 2013; 14: 23-7)

Key words: Microarray, HPV, Colposcopy, abnormal smear, PCR

Received: 22 September, 2012

Accepted: 13 November, 2012
Özet

Amaç: Human Papilloma Virus (HPV) ile servikal neoplaziler arasında iyi bilinen bir ilişki mevcuttur. Bu çalışmanın amacı anormal servikal sitolojili kadınlarda HPV DNA tiplerini araştırmak ve sonuçlanı kolposkopik bulgularla karşılaştırmaktır.

Gereç ve Yöntemler: Genel referans endikasyonlarıla (ASCUS ve üstü smear sonucu) başvuran 76 kadın, sırasıyla geleneksel tanı araçlarıyla (PAP-smear, kolposkopi, punch biyopsi) değerlendirmeye alındı ve tüm hastalar HPV DNA testine tabi tutuldu. HPV DNA tiplemesi için piyasada bulunan PCR bazlı mikroaarray (Genomica-CLART) sistemi kulanıldı. HPV testi, 35 tipi belirleyebiliyordu. (HPV-6/-11/-16/18/-26/-31/-33/-35/-39/-40/-42/-43/-44/-45/-51/-52/-53/-54/-56/-58/-59/61/-62/-66/-70/-71/-72/-73/-81/-83/84/-85/-89).

Bulgular: Tüm hastaların \%44.7 sinde HPV pozitifliği saptandı. HPV pozitifliği yüzdeleri ASCUS; LSIL ve HSIL hastalarında sırasıyla \%35, \%51.9 ve \%77.7 idi. HPV 16 en sık tip olarak bulundu. Hastaların \%6 sında multipl infeksiyon tespit edildi. Biopsi ile ispatlanmış servikal neoplazi olgularının \%57.8 inde HPV pozitifliği saptandı. En sık rastlanan tip HPV 16 (\%54.5) olarak bulundu. Biyopsi ile ispatlanmış sevikal neoplazi vaklarının \%94.7 sinde kolposkopi patolojik olarak değerlendirildi.

Sonuç: Batı ülkelerine kıyasla HPV sıklığının ülkemizde daha düşük olduğu yayınlanmış veri olmakla birlikte, anormal sitolojili kadınlarda HPV sıklık ve dağılımı batı ülkeleriyle benzerlik göstermektedir. Anormal ve normal sitolojili Türk kadınlarındaki HPV sıklık ve dağılımının belirlenmesi için daha ileri ve popülasyon bazlı çalışmalara gereksinim vardır. HPV virüsünün tanımlanmasıyla ilgili teknolojik ilerlemelere rağmen kolposkopik değerlendirme anormal sitolojili kadınlarda hala çok önemli bir tanı aracıdır.

J Turkish-German Gynecol Assoc 2013; 14: 23-7)

Anahtar kelimeler: Microarray, HPV, kolposkopi, anormal smear, PCR

Geliş Tarihi: 22 Eylül 2012

Kabul Tarihi: 13 Kasım 2012 


\section{Introduction}

Cervical cancer is the second most common cancer and one of the leading causes of cancer-related deaths among women worldwide. Epidemiological studies have shown that there is a strong association, consistent in several countries, between human papilloma virus (HPV) and cervical neoplasia, independent of other risk factors $(1,2)$.

According to the statistics of the Ministry of Health and GLOBOCAN 2008, cervical cancer is the $8^{\text {th }}$ most common cancer among women in Turkey $(3,4)$. It has been reported that the range of HPV prevalence among low risk women is between $2-20 \%$ in Turkey $(5,6)$.

The aim of this study is to investigate the prevalance and distribution of HPV genotypes, utilising a microarray system which can define 35 different types of HPV among Turkish women with abnormal cervical cytology and to compare the HPV DNA results with colposcopic findings.

\section{Material and Methods}

Specimens were obtained from 76 patients who were referred to our referral colposcopy clinic at the Department of Obstetrics and Gynecology, İstanbul Medical Faculty, İstanbul University between January 2007 and January 2008. Each participiant gave written informed consent before she was enrolled and the study was approved by the institution. Seventy-six patients with pathological smears were classified into three groups according to their cytological diagnoses: Atypical squamous cells of undetermined significance (ASCUS), Low grade squamous intra epithelial lesions (LGSIL), High grade intraepithelial lesions (HGSIL). For HPV genotyping, we used a commercially avaliable HPV DNA chip (Genomica-CLART®) which detects the HPV genotypes by highly specific and sensitive polimerase chain reacton (PCR) with a new technological platform based on low density arrays.

Cervical biopsy samples were taken from patients with abnormal colposcopic findings in Group I (ASCUS) and Group II (LGSIL), and from all patients in Group III (HGSIL) regardless of the colposcopic findings.

\section{Cytological and histological diagnoses}

Classification of each cytological diagnosis was based on the Bethesda system. Cervical Intraepithelial neoplasia (CIN I, CIN II, CIN III), in situ carcinoma and invasive carcinoma were used for histological diagnosis of cervical lesions to unify the terminology.

\section{HPV tests}

Microarray HPV test (Genomica-CLART ${ }^{\circledR}$ ) was used for HPV genotyping. The HPV microarray system contains 35 type specific probes: HPV 6, HPV 11, HPV 16, HPV 18, HPV 26, HPV 31, HPV 33, HPV 35, HPV 39, HPV 40, HPV 42, HPV 43, HPV 44, HPV 45, HPV 51, HPV 52, HPV 53, HPV 54, HPV56, HPV 58, HPV 59, HPV 61, HPV 62, HPV 66, HPV 70, HPV 71, HPV 72, HPV 73, HPV 81, HPV 82, HPV 83, HPV 84, HPV 85, HPV 89. Detection of different HPV genotypes was achieved by PCR amplification of a $450 \mathrm{bp}$ fragment within the highly conserved L1 region of the virus.

Cervical samples for HPV testing were taken at the beginning of colposcopy with a clean, dry cotton or alginate swab large enough to obtain a good sized sample. No device that could cause bleeding was used, as blood might interfere with the assay. The swab was placed in its tube without any kind of preservation medium and was maintained at $4^{\circ} \mathrm{C}$ if it was to be processed within seven days or at $-20^{\circ} \mathrm{C}$ when processed later. The samples were fixed in buffered formol for the shortest time possible (never more than 24 hours) to avoid DNA degradation. Before and after cutting the sample, the blade was carefully cleaned with xylene to avoid any cross contamination of the samples cut.

\section{Colposcopic evaluation and punch biopsy}

Colposcopic evaluation and HPV test were performed in all patients. Colposcopic biopsy was performed for pathological colposcopic findings. Furthermore, loop electrosurgical excision procedure (Leep) biopsy was performed in all HGSIL (Group III) patients regardless of the colposcopic findings.

\section{Statistical analyses}

The statistical analyses were performed using the SPSS version 15.00. Chi-square and Fisher's exact tests were used to assess the statistical significiance of differences in the prevalence of HPV infection and to evaluate differences in the frequency of multiple infections among various cervical lesions, as well as to compare the other variables. $\mathrm{p}$ values $<0.05$ were considered statistically significant.

\section{Results}

During the one year period, 76 women with pathological cytology were referred to our colposcopy unit. The mean age of the patients was 35.5 (range: 19-62 years). There were no significant differences with respect to decades of life and HPV positivity. Also, menopausal status had no effect on HPV positivity. The patients were classified into three groups according to their cytological diagnoses, such as Group 1 (atypical squamous cells of undetermined significance $=40$ ), Group 2 (low grade squamous intraepithelial lesion=27) and Group 3 (high grade squamous intraepithelial lesion=9).

Overall, $44.7 \%$ of all patients were HPV positive. HPV was positive in $35 \%, 51.9 \%, 77.7 \%$ of the ASCUS, LSIL and HSIL groups, respectively. HPV 16 was the most prevalent type in all groups. HPV 16 and HPV 84 was found in higher prevalence in high grade squamous intraepithelial lesions (HSIL) when compared to other groups $(\mathrm{p}<0.01)$. The rate of HPV types were as follows: $5.8 \%$ for HPV 11, 20.5\% for HPV 6, 32.3\% for HPV 16, 20.5\% for HPV 18, 2.9 $\%$ for HPV 31, 2.9\% for HPV 51, 11.7\% for HPV53, 5.8\% for HPV $58,2.9 \%$ for HPV 59, 8.8\% for HPV $61,11.7 \%$ for HPV $66,2.9 \%$ for HPV 70 and $2.9 \%$ for HPV 84 (Table1). Multiple infections were detected in 5/76 (6\%) women (Table 2).

Colposcopic examination was made in all patients. Abnormal colposcopic findings were found in $20 \%$ (n: 8 ), $40.7 \%$ (n: 11) and $77.8 \%$ (n: 7) of the ASCUS, LGSIL, HGSIL groups, respectively. 
Cervical biopsy specimens were taken from the patients with abnormal colposcopic findings in the ASCUS and LSIL group. Cervical biopsy samples were taken from all patients in the HSIL group regardless of colposcopic findings.

Of the biopsy proven Squamous intraepithelial lesion's (SIL's), $94 \%$ had colposcopic findings and $57.8 \%$ of biopsy proven SILs were HPV positive. The most common HPV type was HPV 16 (54.5\%). There was a statistically significiant correlation between the HPV positivity and biopsy positivity $(\mathrm{p}<0.05)$ (Table 3$)$.

Table 1. Smear results-HPV types

\begin{tabular}{|c|c|c|c|c|}
\hline & $\begin{array}{c}\text { LGSIL } \\
\text { (n:27) }\end{array}$ & $\begin{array}{c}\text { ASCUS } \\
(n: 40)\end{array}$ & $\begin{array}{c}\text { HGSIL } \\
\text { (n:9) }\end{array}$ & p value \\
\hline HPV & $14(51.9 \%)$ & $14(35.0 \%)$ & $7(77.7 \%)$ & 0.147 \\
\hline Type 6 & $3(11.1 \%)$ & $3(7.5 \%)$ & $1(11.1 \%)$ & 0.863 \\
\hline Type 11 & $0(0 \%)$ & $2(5.0 \%)$ & $0(0 \%)$ & 0.397 \\
\hline Type 16 & $3(11.1 \%)$ & $4(10 \%)$ & $4(44.4 \%)$ & $0.024^{*}$ \\
\hline Type 18 & $1(3.7 \%)$ & $5(12.5 \%)$ & $1(11.1 \%)$ & 0.464 \\
\hline Type 31 & $1(3.7 \%)$ & $0(0 \%)$ & $0(0 \%)$ & 0.399 \\
\hline Type 51 & $1(3.7 \%)$ & $0(0 \%)$ & $0(0 \%)$ & 0.399 \\
\hline Type 53 & $2(7.4 \%)$ & $2(5.0 \%)$ & $0(0 \%)$ & 0.686 \\
\hline Type 58 & $1(3.7 \%)$ & $1(2.5 \%)$ & $0(0 \%)$ & 0.832 \\
\hline Type 59 & $1(3.7 \%)$ & $0(0 \%)$ & $0(0 \%)$ & 0.399 \\
\hline Type 61 & $0(0 \%)$ & $2(5.0 \%)$ & $1(11.1 \%)$ & 0.295 \\
\hline Type 66 & $2(7.4 \%)$ & $2(5.0 \%)$ & $0(0 \%)$ & 0.686 \\
\hline Type 70 & $0(0 \%)$ & $1(2.5 \%)$ & $0(0 \%)$ & 0.634 \\
\hline Type 84 & $0(0 \%)$ & $0(0 \%)$ & $1(11.1 \%)$ & $0.023 *$ \\
\hline \multicolumn{5}{|c|}{$\begin{array}{l}* \text { : p<0.05, HPV: Human papilloma Virus, LGSIL: Low Grade Sguamous } \\
\text { intraepithelial lesion, HGSIL: High Grade Squamous intraepithelial lesion, } \\
\text { ASCUS: Atypical squamous cells of undetermined significance }\end{array}$} \\
\hline
\end{tabular}

Table 2. Multiple infections

\begin{tabular}{|c|c|c|c|c|}
\hline AGE & SMEAR & \begin{tabular}{|l} 
HPV \\
TYPES
\end{tabular} & COLPOSCOPY & $\begin{array}{l}\text { HISTOPATHOLOGIC } \\
\text { DIAGNOSIS }\end{array}$ \\
\hline 26 & ASCUS & $\begin{array}{l}\text { HPV6, } \\
\text { HPV53, } \\
\text { HPV 58 }\end{array}$ & NEGATIVE & NEGATIVE \\
\hline 25 & ASCUS & $\begin{array}{l}\text { HPV 6, } \\
\text { HPV 11, } \\
\text { HPV18, } \\
\text { HPV 53 }\end{array}$ & AWE & CIN III \\
\hline 41 & LGSIL & $\begin{array}{l}\text { HPV16, } \\
\text { HPV18 } \\
\end{array}$ & NEGATIVE & NEGATIVE \\
\hline 34 & HGSIL & \begin{tabular}{|l|} 
HPV16, \\
HPV18
\end{tabular} & NEGATIVE & $\begin{array}{c}\text { IN SITU } \\
\text { CARCINOMA }\end{array}$ \\
\hline 46 & LGSIL & \begin{tabular}{|l|} 
HPV6, \\
HPV 59
\end{tabular} & NEGATIVE & NEGATIVE \\
\hline \multicolumn{5}{|c|}{$\begin{array}{l}\text { AWE: Acetowhite epithelium, HPV: Human papilloma Virus, LGSIL: Low Grade } \\
\text { Sguamous intraepithelial lesion, HGSIL: High Grade Squamous intraepithelial } \\
\text { lesion, ASCUS: Atypical squamous cells of undetermined significance, CIN } \\
\text { Cervical intraepithelial neoplasia }\end{array}$} \\
\hline
\end{tabular}

\section{Discussion}

Epidemiological studies and experimental research have established a causal link between the presence of HPV 16, HPV 18, HPV 31, HPV 33, HPV 35, HPV39, HPV 45, HPV 51, HPV 52, HPV 56, HPV 58, HPV 59, HPV 66 and the development of invasive cervical cancer $(7,8)$. It has also been estimated that HPV is responsible for $5.2 \%$ of all cancers worldwide (9).

The HPV microarray system is a newly developed biotechnology that can be applied to clinical practice for the detection and genotyping of HPV. The application of microarray technology as a diagnostic tool shows great advantages since microarrays can discriminate the HPV genotype and identify multiple infections. In our study, the microarray system (microarray genomica) could detect 35 types of HPV.

It has been reported that the HPV detection rates of the microarray technique is comparable to hybrid capture II ( $\mathrm{HCII}$ ) and it is also able to determine multiple lesions $(10,11)$. Kim et al. (10) reported that the HPV testing methods have comparable sensitivities (94.9\% for HC-II and 93.7\% for HPV microarray) for detection of SIL. The sensitivity, specificity, positive and negative predictive values of HPV testing by HC-II and HPV microarray methods were not significantly different.

Table 3. HPV types and colposcopic results of biopsy proven lesions

\begin{tabular}{|c|c|c|c|}
\hline Smear & Colposcopy & HPV & Biopsy \\
\hline ASCUS & Mosaic pattern & Negative & CIN II \\
\hline ASCUS & AWE & Negative & CIN III \\
\hline ASCUS & Mosaic pattern & Negative & CIN II \\
\hline LGSIL & Mosaic pattern & Negative & CIN II \\
\hline LGSIL & Mosaic pattern & Negative & CIN II \\
\hline LGSIL & AWE & HPV type 6 & CIN II \\
\hline LGSIL & AWE & HPV type 31 & CIN II \\
\hline LGSIL & AWE & Negative & CIN II \\
\hline LGSIL & Mosaic pattern & HPV type 51 & CIN III \\
\hline LGSIL & Mosaic pattern & HPV type 16 & CIN III \\
\hline LGSIL & AWE & HPV type 16 & CIN II \\
\hline HGSIL & Mosaic pattern & HPV type 16 & CIN III \\
\hline HGSIL & Mosaic pattern AWE & HPV type 16,18 & CIN III \\
\hline HGSIL & AWE & Negative & CIN III \\
\hline HGSIL & Mosaic pattern & HPV type 61,84 & CIN III \\
\hline HGSIL & AWE & HPV type 6 & CIN III \\
\hline HGSIL & Lesion positive & Negative & İnvasive ca \\
\hline HGSIL & Mosaic pattern & HPV type 16 & CIN III \\
\hline HGSIL & $\begin{array}{c}\text { Negative (normal } \\
\text { colposcopic finding) }\end{array}$ & HPV type 16 & In situ ca, \\
\hline \multicolumn{4}{|c|}{$\begin{array}{l}\text { AWE: Acetowhite epithelium, HPV: Human papilloma Virus, LGSIL: Low } \\
\text { Grade Sguamous intraepithelial lesion, HGSIL: High Grade Squamous int- } \\
\text { raepithelial lesion, ASCUS: Atypical squamous cells of undetermined signif- } \\
\text { cance, CIN: Cervical intraepithelial neoplasia }\end{array}$} \\
\hline
\end{tabular}


In women with abnormal cytology results, the presence of HPV infection has been reported in $28.8-61.3 \%$ of cases wordwide $(12,13)$.

In a Turkish study, the HPV prevalence has been reported in 36\% of cases with abnormal cytology (6). Inal et al. (5) performed a HC-II study in 1353 women from the Izmir region, which has the highest cervical cancer incidence in Turkey, and reported that all the women with cytological abnormalities had positive HPV DNA. In our study, HPV was positive in $44.7 \%$ of the women with abnormal cytology and HPV 16 was the most prevalent type.

The published data from Turkey reveals us that the HPV prevalence is $3-20 \%$ in a low risk population $(5,6)$. Although it has been reported that the HPV prevalence is lower than reported worldwide in the low risk population, HPV prevalence and type distribution with abnormal cytology in our study was similar to that reported worldwide. It should be borne in mind that there is no population based study investigating HPV prevalence in Turkish women and the published data for HPV prevalence is limited.

International prevalence surveys by the International agency for Research on Cancer (IARC) have shown that the most prevalent HPV types of invasive cervical cancer were HPV 16 (53\%), HPV 18 (15\%), HPV 45 (9\%), HPV 31 (6\%) and HPV 33(3\%) (14). In various studies, HPV 51, HPV 52, HPV35, HPV 56 and HPV 58 were found to be the common types in premalignant conditions $(10,15)$. Dursun et al. from Turkey reported that the most common HPV types in cytologically abnormal women were HPV 16 (35\%), HPV 6 (19\%) and HPV 18 (8.8\%) (6).

In our sudy, the prevalence of HPV 16 and HPV 18 was found to be lower than in other reports, whereas HPV 53 and HPV 66 were found to be the second common type in pathological smears. In addition, HPV 16 and HPV 84 were significantly higher in the HSIL group. However, the number of our patients is inadequate to make a a comment.

HPV-84 was more commonly detected than HPV-16 or any other HPV genotype in people with incidental HPV infection in men genital specimens (16). HPV 84 has been considered as a low-risk HPV type and was detected in $3.3 \%$ of females aged between 14-59 in United States (17).

Although HPV 84 has been considered as a low risk HPV type, recent studies showed that it was detected in $13.9 \%$ of biopsy proven cervical intraepithelial lesions and was more associated with HSIL or worse as compared to all other types together (18).

A study for the association between HPV DNA positivity and the subsequent development of cervical cancer showed that the HPV DNA type in all women with cervical cancer was the same in the baseline smear and in the biopsy specimen. None of the control women had the same type of HPV in both smears (8). The stong concordance between the type of HPV found in the baseline smears and that found in the biopsy specimen of the invasive cancer further supports the importance of viral subtyping.

Colposcopic evaluation and guided biopsy are important diagnostic steps and standards of management for abnormal cytology smears The performance and accuracy of colposcopy depend largely on the training, experience, and skills of the colposcopist. Hence, accuracy of colposcopy varies widely among studies in different parts of the world. In a meta-analysis, it has been reported that the sensitivity of colposcopy varies between $87-99 \%$ (19). The sensitivty of HPV DNA test to detect high grade lesions in ASCUS and LSIL groups ranges between 92.5-97.5\% (20). According to an American Society for Colposcopy and Cervical Pathology (ASCCP) concensus in 2006, HPV testing and colposcopy are reasonable options for the management of patients with ASCUS and LSIL cytology.

In our study, $94.7 \%$ of biopsy proven SILs had abnormal findings at colposcopic evaluation. Statistically significant correlations were found between smear and colposcopic results. For ASCUS, LSIL and HSIL groups, $20 \%, 40 \%$ and $77.8 \%$ of the colposcopic evaluation were positive, respectively. Overall, 57.8 $\%$ biopsy proven cervical neoplastic lesions were HPV positive. Three cases with ASCUS cytology who had biopsy proven SIL were negative for HPV. In the LSIL group, $62.5 \%$ of the biopsy proven SILs were HPV positive.

Our data is limited to making a recommendation. Nevertheless, the HPV DNA test without colposcopic evaluation could be the cause of misdiagnosis in our cases, particularly in the ASCUS group. In our study, all of the colposcopic evaluations were made by experienced colposcopists. This could explain the strong correlation between colposcopy and biopsy.

\section{Conclusion}

Although it has been reported that the prevalence of HPV in the general population is lower than Western countries, the prevalance and genotypes are smilar in patients with abnormal cytology. This could be attributed to the limitations of the studies from Turkey, methodology and hospital based patient population. Further population based studies are needed to determine the prevalence and distribution of the HPV types with normal and abnormal cytology in Turkish women.

Colposcopic evaluation is a very important diagnostic tool for the detection of cervical intraepithelial lesions. Despite the major advances in the development of new technologies, the value of colposcopy in the management of abnormal smears remains stable.

\section{Conflict of interest}

No conflict of interest was declared by the authors.

\section{References}

1. Bosch F, Manos M, Munoz N, Sherman M, Jansen A, Peto J, et al. Prevalence of human papillomavirus in cervical cancer: a worldwide perspective. International biological study on cervical cancer (IBSCC) Study Group. J Natl Cancer Inst 1995; 87: 796-802. [CrossRef]

2. Walboomers JM, Jacobs MV, Manos MM, Bosch FX, Kummer JA, Shah KV, et al. Human papillomavirus is a necessary cause of invasive cervical cancer worldwide. J Pathol 1999; 189: 12-9. [CrossRef]

3. Sağlık bakanlığı 2002. Kanserle Savaş Derneği, kanser kayıtlarında öncelik verilecek 8 il raporu (Ministiry of health reports)

4. WHO/IARC Globocan 2008 http://www-dep.iarc.fr/globocan/database.htm 
5. Inal MM, Köse S, Yildirim Y, Ozdemir Y, Töz E, Ertopçu K, et al. The relationship between human papillomavirus infection and cervical intraepithelial neoplasia in Turkish women. Int $\mathrm{J}$ Gynecol Cancer 2007; 17: 1266-70. [CrossRef]

6. Dursun P, Senger S, Arslan H, Kuşcu E, Ayhan A. Human papillomavirus (HPV) prevalence and types among Turkish women at a gynecology outpatient unit. BMC Infect Dis 2009; 9: 191. [CrossRef]

7. Burd E. Human papillomavirus and cervical cancer. Clin Microbiol Rev 2003; 16: 1-17. [CrossRef]

8. Schiffman M, Herrero R, Desalle R, Hildesheim A, Wacholder S, Rodriguez AC, et al.The carcinogenicity of the human papillomavirus types reflects viral evolution. Virology 2005; 337: 76-84. [CrossRef]

9. Parkin DM. The global health burden of infection-associated cancers in the year 2002. Int J Cancer 2006; 118: 3030-44. [CrossRef]

10. Kim C, Jeong J, Park M, Park T, Park T, Namkoong S, et al.HPV oligonucleotide microarray based detection of HPV genotypes in cervical neoplastic lesions. Gynecologic Oncology 2003; 89: 210-7. [CrossRef]

11. Tao PP, Bian M, Ou H, Chen Q, Li M, Liu J. Application research on the flow through hybridization and gene chip in human papillomavirus detection. Zhonghua Fu Chan Ke Za Zhi 2006; 41: 43-7.

12. González-Bosquet E, Esteva C, Muñoz-Almagro C, Ferrer P, Pérez $\mathrm{M}$, Lailla JM. Identification of vaccine human papillomavirus genotypes in squamous intraepithelial lesions (CIN2-3). Gynecol Oncol 2008; 111: 9-12. [CrossRef]
13. Levert M, Clavel C, Graesslin O, Masure M, Birembaut P, Quereux C, et al. Human papillomavirus typing in routine cervical smears. Result from a series of 3778 patients. Gynecol Obstet Fertil 2000; 28: 722-8. [CrossRef]

14. Muñoz N. Human papillomavirus and cancer: the epidemiological evidence . J Clin Virol 2000; 19: 1-5. [CrossRef]

15. Nakagawa S, Yoshikawa H, Onda T, Kawana T, Iwamoto A, Taketani Y. Type of human papillomavirus is related to clinical features of cervical carcinoma. Cancer 1996; 78: 1935-41. [CrossRef]

16. Partridge JM, Hughes JP, Feng Q, Winer RL, Weaver BA, Xi LF, et al. Genital human papillomavirus infection in men: incidence and risk factors in a cohort of university students. J Infect Dis 2007; 196: 1128-36. [CrossRef]

17. Dunne EF, Unger ER, Sternberg M, McQuillan G, Swan DC, Patel SS, et al. Prevalence of HPV infection among females in the United States. JAMA 2007; 297: 813-9. [CrossRef]

18. Choi Y, Han C, Chung W, Jung W, Lee J, Nam J. Analysis of HPVother samples by performing HPV DNA sequencing. Korean Journal of Pathology 2009; 250: 43-5.

19. Mitchell MF, Schottenfeld D, Tortolero-Luna G, Cantor SB, RichardsKortum R. Colposcopy for the diagnosis of squamous intraepithelial lesions: a meta-analysis. Obstet Gynecol 1998; 91: 626-31. [CrossRef]

20. Arbyn M, Paraskevaidis E, Martin-Hirsch P, Prendiville W, Dillner J. Clinical utility of HPV-DNA detection: triage of minor cervical lesions, follow-up of women treated for high-grade CIN: an update of pooled evidence. Gynecol Oncology 2005; 99: 7-11. [CrossRef] 